\title{
The future of the energy transition in Germany
}

\author{
Erik Gawel ${ }^{1 *}$, Paul Lehmann ${ }^{1}$, Klaas Korte ${ }^{1}$, Sebastian Strunz ${ }^{1}$, Jana Bovet ${ }^{1}$, Wolfgang Köck ${ }^{1}$, Philipp Massier ${ }^{2}$, \\ Andreas Löschel ${ }^{2}$, Dominik Schober ${ }^{2}$, Dörte Ohlhorst ${ }^{3}$, Kerstin Tews ${ }^{3}$, Miranda Schreurs ${ }^{3}$, Matthias Reeg ${ }^{4}$ \\ and Sandra Wassermann ${ }^{5}$
}

\begin{abstract}
Although the goals of the country's energy transition (Energiewende) are widely accepted in Germany, the specific route to get there is itself a matter of great controversy. The individual measures that are part of the energy transition policy and the questions of how they interact and how they are embedded in the European context are objects of controversial scientific and public debate. Most recently, the consequences for the price of electricity have, in particular, been discussed intensely. Against this backdrop of wide-ranging criticism, the future course for promoting renewable energy will soon be set. The German Renewable Energy Sources Act (the Erneuerbare-Energien-Gesetz, EEG), which is the main instrument of energy transition policy with its feed-in tariffs, is supposed to be fundamentally revised in the course of this year. A precondition for achieving a coherent further development of the energy transition policy and for receiving the sound support of a critical public is that the long-term consequences of political decisions on a complex sociotechnical energy system be taken into account. The requirements of such a system are not satisfied by policy approaches or recommendations that target short-term effects or that are perceptions of problems extrapolated from individual sectors. On the basis of its integrated research on the energy transition, researchers from the Helmholtz Alliance Energy-Trans take a stand on current important controversial issues from the energy transformation and specify fundamental challenges to shaping a sustainable energy transition policy.
\end{abstract}

Keywords: Energy transition; Sustainability; Germany; European Union; State aid; Renewable energy sources; Feed-in tariff; Federalism; Energy policy; Market design

\section{The energy transition: a long-term project and a challenge to the system}

The energy transition in Germany is nothing less than the restructuring of the entire energy supply in the sectors' electricity, heat, and transportation in a highly industrialized country. This comprehensive reorganization is a task for generations, and yet the fundamental framework has to be created today. Although there continues to be a high level of approval in the general public [1-4] and among all political forces [5], essential components of the German energy transition policy are themselves currently being subject to criticism, some of it very intense. The focus of this criticism is most frequently on the renewable energy supports provided for the generation of electricity, which take the form of feed-in tariffs permitted by the Renewable Energy Sources Act (Erneuerbare-Energien-

\footnotetext{
* Correspondence: erik.gawel@ufz.de

${ }^{1}$ Helmholtz Center for Environmental Research - UFZ, Permoser Str. 15, 04318 Leipzig, Germany

Full list of author information is available at the end of the article
}

Gesetz (EEG)). ${ }^{a}$ Challenges to the energy transition go, however, far beyond this. What is required is a long-term process of transforming a complex sociotechnical system $[6,7]$ in which the goal is to set the course of change so that tomorrow's energy supply works, its consumption of resources, and its impact on the environment are limited to a sustainable level, and, in the process, efficiency and social acceptance are safeguarded. Political activity should always keep this long-term systemic perspective in sight. Policy that is directed toward short-term, purely sectoral based indicators, such as the allocation of costs in the EEG (the levy or surcharge), does not do this justice $[8,9]$.

\section{Energy transition policy under scrutiny}

A complex and sweeping enterprise such as the energy transformation project must nonetheless - and quite rightly - justify to a critical public that the overall policy framework for such substantial structural changes is correctly set and confirm that unnecessary costs are not being imposed on the national economy. Agreement on

\section{实}


the goals of restructuring always has to come at the beginning of reforms [8]. The instruments for the subsequent implementation should be continuously adapted in accordance with a process-based control strategy that is open for corrections $[10,11]$, since it is impossible today to foresee every future challenge and necessary measure. For this reason, the review that is currently underway, particularly of the EEG, is in principle to be welcomed. Regular corrections and realignments are inevitable if new but suboptimal routes of development are to be prevented from becoming stabilized and rigid.

\section{The cost of the renewable energy expansion: an objective debate is essential}

The debate over reforms that has started in the meantime is falling short. It is strongly focused on the power sector, the current consumer prices, and the influence of the EEG levy on these prices. This reductionism blocks our view both for the socioeconomic connections and for the real challenges to energy policy. The heat and transportation sectors are also central to a sustainable transformation of our energy system, not just the power supply [12]. ${ }^{\mathrm{b}}$ From the perspective of the national economy, the costs that are at issue cannot be limited to those printed right on the electricity bill. Other external costs - in addition to $\mathrm{CO}_{2}$, there are also local environmental issues - as well as special benefit dimensions, such as learning curve effects of technology development, also have to be taken into consideration [10,13-15]. Furthermore, to be fair, every form of subsidy for an energy carrier has to be taken into consideration, even those via financing channels other than the price of electricity [16]. The current debate about the price of electricity does not take all of this into account and turns our attention for day-to-day political matters to issues that are not at the heart of the challenges facing the transformation. Against this backdrop, it is clear that a more objective debate about costs is urgently necessary, as is a reorientation of the reform agenda.

\section{Support for renewables still sensible}

There are still good reasons to continue a policy of supporting renewable energy, at least in principle. Neither have we come even remotely close to reaching our ambitious goals for expanding it, nor do the current market prices cover the relevant costs to the national economy, which would represent the possibility for the market alone to maintain undistorted, fair technological competition to determine the most favorable manner of generating energy $[13,15,17]$. The additional costs for renewable energy, i.e., those beyond the price achieved on the power exchange, will drop again considerably anyway. The exchange prices, which in the medium term will be oriented on the long-term marginal costs of the conventional power plants still producing electricity - and which will rise again after the excess capacity is disposed of - contribute to this. Likewise, a more robust European Union (EU) emissions trading system would have a corrective effect on the distorted exchange prices. For these reasons (incomplete internalization of external effects, subsidies for conventional power generation, electricity prices on the exchange that are too low) and because of the neglect of the future price development, renewable energy continues to exhibit strategic disadvantages in the public's perception of costs and in a comparison of market prices with conventional energy carriers, which says nothing about their actual long-term competitiveness [18]. In this respect, the support for renewables is currently not up for disposal, but it is up for renewed goal-oriented development. This has to be undertaken with due regard for the possible effects of distortions of support policies for renewables [19]. Consequently, it must be ensured that the goal is achieved in a more cost-efficient manner, not just an effective one [20].

\section{Keeping an eye on the social distribution of costs}

The discussion of the costs and utility of the energy transformation for society cannot be restricted to their appropriate amounts. Their distribution to individuals, groups, and regions belongs to the challenges facing responsible policy making. In particular, the distribution of the burden resulting from the energy transformation may not be intransparent or in contradiction to the fundamental values of fairness. Above all, the extensive and sometimes objectively groundless number of exceptions for industry from the financing of the expansion of renewable energy by all the consumers of electricity meets with substantial misgivings [21,22] and has become the object of European proceedings for inappropriate state aid (see the following section) [23]. The EEG-levy exceptions for industry ${ }^{\mathrm{c}}$ have been repeatedly expanded in the past. They should - independent of the requirements of European law - rapidly be limited to a realistically tenable amount that is aligned on the proven dangers to international or intermodal competitiveness [21,22,24]. A company's energy consumption, the measure currently used by the $E E G$, is an unsuitable indicator for this purpose.

\section{Conformity of the EEG with European state aid regulations}

A current object of scrutiny with regard to European regulations is the preferential treatment provided for by the EEG. The prohibition of state aid forbids the use of state funds to provide preferential treatment to certain enterprises or branches regardless of their nature if it distorts competition in Europe's internal market or threatens to do so (Article 107(1), Treaty on the Functioning of the European Union (TFEU)). This leads to requirements for 
structuring of the renewable energy policy. The European Court of Justice (ECJ), however, decided in 2001 that the law regulating the feed in of electricity of that time conformed to EU state aid regulations because it did not constitute state aid. This law obliged energy supply companies and network operators to purchase electricity from renewable sources of energy at a price set by law which was above the market price - and to pass on the additional costs in a compensation system run by the network operators and energy suppliers. This was the case since no state aid was transferred to the companies that produced the power either directly or indirectly [25]. Yet, this decision does not provide a free pass for every kind of further development of the EEG (see e.g., [26]). Decisive is, first, whether the financing and compensation mechanism in the present EEG represents an organization of financial streams that can be assigned to the category of the state sphere of financing and thus whether the act of providing state aid is present at all. ${ }^{d}$ Even then, this might not have any consequences insofar as there is no threat of a distortion of competition or it is at least shown to be a justified exception according to European law, which in principle has also been acknowledged by the European Commission with regard to promoting the use of renewable energy ([27], p. C 74]). The Commission, however, affirms that the EEG constitutes state aid and for this reason also doubts that the so-called green power privilege $(\$ 39 \mathrm{EEG})^{\mathrm{e}}$ and the EEG-levy exemptions for energy-intensive companies (\$ $40 \mathrm{ff}$. EEG) conform to European law because it suspects a distortion of competition in both cases ([27], p. C 74 et seq.]). The Commission has therefore recently initiated a formal investigation of Germany. ${ }^{\mathrm{f}}$ With regard to the issue of whether the EEG system of supports and compensation constitutes state aid, the Commission's legal opinion is far from compelling because the role of the state authorities is very limited, no state or semistate fund is established, and the system using a levy and a reduction in charges continues to rely on private law for participants to assert their claims. ${ }^{\mathrm{g}}$ There are therefore good reasons to assume that the current EEG system will not be subject to the scope of EU rules on state aid. ${ }^{\mathrm{h}}$ Yet, it is by no means guaranteed that the EEG system will be found to conform to these rules. If the EEG mechanism is found to have the character of state aid, then EU law offers possibilities for justifying its form (e.g., Article 107 (3) lit $\mathrm{b}$ TFEU) or for structuring the aid in a manner that conforms to EU law. i To do the latter, environmental guidelines of the European Commission [28] are employed, which are currently being revised parallel to the legal actions [29], completely confusing the future legal situation. The compatibility of the EEG with European rules on state aid is essential for the further development of the EEG. Until these difficult legal issues are clarified, which can possibly drag on for years until there is another decision by the European Court of Justice, the pending reform of the EEG must be pushed on keeping in mind the issue of conformity to European law, not however according to the Commission's unauthoritative legal stance. This means a consistent curtailment of the present volume of the EEG-levy exemptions for the power-intensive fields of manufacturing, restricting application of the rule to those cases where its application would obviously result in distortion of competition. Attention must be paid to ensure that the selection of branches of the economy that are given relief and the amount of the relief are in conformity to the EU regulations on state aid. Furthermore, other examples in the EEG of preferential treatment (e.g., the green power privilege) should be examined from the perspective of nondiscriminatory competition in the European single market. Both of these have already been agreed upon in the current government's coalition agreement and may well point in the right direction in terms of European law.

\section{Maintaining a social balance}

The social consequences of the energy transition policy should always be taken into consideration, yet without playing off social policy against energy, environmental, and climate policy [30-32]. Those who are socially weak must be able to keep up during the restructuring of the energy system. ${ }^{k}$ Appropriate relief from the EEG levy can even be provided to private households, by the way, by reform measures that are advisable in terms of energy policy anyway. This includes making the European emissions trading system more robust (see 'Strengthening the EU emissions trading and use the chances offered by European inclusion' section), which would lead to higher prices in the electricity market and thus correspondingly to a lower cost differential that would have to be covered by the levy. Another effect would be the decrease in the excessive privileges enjoyed by industry (see 'Keeping an eye on the social distribution of costs' and 'Conformity of the EEG with European State Aid Regulations' sections) in the context of the EEG levy, which also could lower the corresponding burden on private households. ${ }^{1}$ Furthermore, measures focused on policies to improve energy efficiency (see 'Urgent fields of action other than the generation of electricity: pushing energy efficiency' section) constitute a sensible contribution to providing relief to lower-income groups without compromising the goals of the energy transition $[33,34]$.

\section{How to continue with the German Renewable Energy Sources Act?}

The success of the present philosophy for providing support in the EEG has in the meantime reached its limits, making a reorientation necessary. The size of the EEG 
levy is, however, not an unqualifiedly suitable measure for political action for it depends on numerous distorting factors, such as the exchange price and the extent to which levy reductions are granted (e.g., for industrial use and for self-generated electricity) [35]. The EEG levy does not immediately reflect the cost of the transition to renewables to the entire economy, which also includes any later consequences of the energy supply that are ecological or social in nature [36]. The expert commission conducting the monitoring process called 'Energy of the Future' has made suggestions for indicators that are far more suitable [8]. The envisaged reform of the EEG should therefore abstain from organizing a simple limit to the levy. A revision of the Act must not be driven by the lack of a unit for measuring the cost of the EEG levy, but must initiate a structural reform that is sustainable in the medium term. Such a reform must be based on a comprehensible analysis of the problem and a clear ranking of the political goals [18]. After providing supports for 20 years, it is right to reset the priorities in the direction of sustainable and less costly technology. In particular, consideration should be given to the consequences the EEG's market incentives have on the regional distribution of production (e.g., primarily on the windy costal locations or rather closer to the consumption in the country's interior). In doing so, neither support for renewable energy as such should be challenged nor should the general framework for urgently required investments be subject to all too abrupt changes.

\section{The challenge of designing the future electricity market}

Following a reform of the EEG, thought must be given to a new holistic design of the electricity market in the medium term. Currently, there is no reason to undertake any far-reaching interventions in the framework of the electricity market that would bind us for a long term. The current low prices on the power exchange that are the object of complaints because they are thought to be problematic for operators of conventional power plants are the expression - in a manner, completely in keeping with the market - of an excess supply of capacity for generating electricity and of the lack of impulses from the European emissions trading system (see 'Support for Renewables Still Sensible' section) but not of the unsuitability of the present market design. Restraint is therefore advisable with regard to considerations of the short-term introduction of capacity mechanisms that are supposed to give additional income to conventional power plants at the consumers' expense today because of fears that there will be bottlenecks in the future. Although it is necessary for volatile renewable forms of energy to be subject to scrutiny and study in order to ensure the long-term supply in future periods, there is no acute need for political action. ${ }^{\mathrm{m}}$ The debate has turned much too quickly to the question of how a mechanism promoting the expansion of capacity could look in concrete terms, even before the necessity of such an institutional innovation has been viably justified at all. The available time should rather be utilized to make a thorough determination of the problems that can actually be expected to afflict a future secure supply of power and to prepare the design of the future electricity market accordingly. To solve such capacity-based supply problems, the potential savings from making demand more flexible, from expanding the network and storage, and from the cogeneration of heat and power should be examined as a matter of principle in addition to considering a possibly expensive realignment of the design of the electricity market [37]. Constant attention must be given to an efficient organization of the various markets in order to keep the costs of the energy transition under control in this respect, for example, for the flexibility reserves that will be necessary in the future [38].

\section{Urgent fields of action other than the generation of electricity: pushing energy efficiency}

Achieving an efficient use of the available energy is, after the expansion of renewable energy, the most important task in the field of power supply. The pace of energy efficiency - which until now has been inadequate - must be forced considerably. ${ }^{\mathrm{n}}$ Estimates made by dena (The German Energy Agency or Deutsche Energie-Agentur) assume that the use of electricity in private households can be decreased by up to $25 \%$ as a result of the use of energy-efficient devices and optimized consumer behavior [39]..$^{\mathrm{o}}$ The substantial potential ${ }^{\mathrm{p}}$ for improving technical efficiency throughout the entire electricity sector - in the generation, transformation, and transportation - and for saving power have to be utilized as far as this can be done in a cost-effective manner. ${ }^{\mathrm{q}}$ This mitigates the necessity of replacing energy carriers and limits the necessary expansion of renewable energy. Precisely, the power prices criticized as being high contribute in a market-based system as an incentive for investments in energy efficiency and for saving energy. The price of electricity is not a stroke of fate but a sign of scarcity that admonishes us to adopt efficient consumer behavior, which can effectively limit the cost burden. Active competition in the power exchanges and a change in provider by consumers can contribute to easing the burden in a manner in keeping with the market [15]. As a consequence, interventions in the price of power that are motivated by social reasons or industrial policy should not be pursued [30].

\section{Further develop grids and storages as complementary components of energy infrastructure} Storage and networks constitute important complementary forms of infrastructure in the power sector and 
must be further developed to enable them to adopt modified and entirely new tasks in the sustainable energy supply system of tomorrow. In this way, the reserve capacity that will be needed in the future in addition to the renewable capacity will be reduced, and the degree of utilization, especially of feature-dependent renewable energy (sun, wind), will be improved. A much improved coordination between the expansion of generation and the network infrastructure will make a necessary contribution to this $[10,11]$. At the same time, another goal must be an efficient management of the network, in which power suppliers as a matter of principle take the needed transportation costs in the network into account when they make decisions about future locations [20,40]. The optimization of the entire system (generator plants, networks, storage) will at the same time reduce the pressure on generation, especially on the supports for renewable sources. It is obvious that the EEG alone cannot bear the responsibility for the performance and for the costs of the difficult system transformation in the power sector.

\section{Push the energy transition in the sectors' heat and transportation as well}

In order to achieve the goals of the energy transition, substantial efforts are needed in the fields of heat and transportation in addition to the measures in the area of power supply. Both the supply of heat from renewable energy and the energy efficiency of buildings unjustly take a back seat in the attention of both the public and politicians to that given the supply of power [41-43]. In light of the special potential for savings in those areas, it is urgent that a coherent plan be developed as to how measures to improve efficiency in the building stock can be linked with the use of renewable sources for the generation of heat $[44,45]$. At the same time, it is of great importance for the acceptance of such policy measures that questions regarding allocation, in particular, between renters and property owners, as well as incentive problems $[46,47]$ be given full consideration $[48,49]$. Similarly, systematic incentives are to be developed in the area of transportation [50]: to complement the ambitious formulation of political goals, instruments have to be created quickly to implement such incentives. We are unable in this context to delve deeper into these extremely important complementary modules in the energy transition.

\section{Strengthen the EU emissions trading and use the chances offered by European inclusion}

The integration of Germany's energy policy in the European framework deserves, if nothing else, to be paid attention to. Germany's future energy policy has to consistently take advantage of the chances offered by European integration. This means that a balance must be struck between European integration and national energy transition policy.
The German energy transition is appropriately integrated in European climate policy, in the expanded use of renewable energy, and in energy efficiency policy until at least 2020, via the common European framework of goals [51]. Particularly from the German perspective, adhering to its separate goals for expanding the use of renewable energy and for improving energy efficiency can be sensible at the European level and even beyond 2020 if this means that externalities other than the reduction of $\mathrm{CO}_{2}$ emissions can be addressed. This is in fact plausible [52,53] since globally numerous environmental damages or risks, even interregionally relevant ones, are linked to the acquisition and use of nonrenewable energy carriers, starting with the decomposition of the energy carriers (e.g., the consumption of land by strip mining of coal), including their use to generate electricity, heat, and power (particulate emissions, nuclear incidents) or the problematic of import risks that have not been priced in, up to disposal (radioactive waste). ${ }^{r}$ At the European level, interactions between the expansion of renewable energy with the fixed volume goal for $\mathrm{CO}_{2}$ set by the European emissions trading scheme must definitely be taken into account in order to avoid overendowing them with certificates in the future

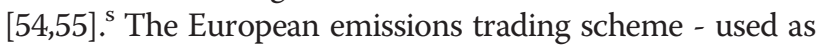
an internalization lever for climate follow-up costs - is one of the most important instruments of environmental energy policy in the European context. It is essential that its functioning be retained and strengthened. An effective emissions trading system contributes to the reduction in distortions in competition that results in a burden on environmentally friendly renewable energy and at the same time prevents a fall in the prices on the power exchange [56]. Furthermore, strong European coordination of the national measures regarding energy policy will contribute to opening up synergies and reducing costs. For the areas of the EU internal market and the trans-European networks, the authority that the EU already has should be utilized systematically. Regarding the expansion of renewable energy, in contrast, it appears more realistic to place one's bets on a decentralized process of convergence under the umbrella of EU objectives, such as through the linkage of the national systems of supports [51].

\section{The role of the state in the energy transition}

The preceding developments concerning energy policy have engendered numerous misgivings with regard to the strong role played by the state and to the regulation of the energy sector of the economy that is increasingly being perceived as being aloof of the markets. State interventions are, however, indispensable where various market failures appear in the energy sector. It is necessary for corrective interventions to be taken where the current market prices do not reflect the social truth 
either economically or ecologically. Today's infrastructure consisting of power plants and networks and the corresponding regulatory framework has been optimized for the centralized generation of electricity using continuously available energy carriers. The long-term investments that have been made lead to the conviction that the shifting of the system to decentralized, renewable technology whose production is volatile does not make any business sense even if it is desirable for the economy overall. Finally, barriers in technology development, restrictions in the capital markets, problems of local acceptance, and protracted approval procedures impede the necessary changeover and cannot be overcome solely by market-based mechanisms [10,13,57]. There are therefore good reasons for the state to currently play a leading role in the energy transition.

\section{Stable framework instead of a zigzag route}

The energy transition is a large-scale societal project requiring private and public investments in the billions. The risk involved must especially be born privately, and the investments must point in the right direction for the entire economy. Politics bears the responsibility for both. We therefore need clear and unambiguous incentives as well as a framework that is stable for the medium term and that refrains from constantly changing the rules of law and the conditions of investment. This will also prevent investments from being depreciated post hoc that were made in confidence in the continuance of energy policy rules. Efforts at reform therefore always have to take into consideration the commandment to observe the 'constancy of economic policy' [58]. . $^{\text {t }}$

\section{Coordinating the energy transition in the federal system}

The federal system of the Federal Republic of Germany offers great chances for innovative decentralized solutions. The cities, regions, and states form a framework suitable for the development of innovative solutions adapted to decentralized forms of technology (competitive federalism). Moreover, the guarantee of community self-management provides the institutional basis for active local energy policies that serve as role models [59,60]. Making the energy transition a success does not only depend on maintaining or expanding the opportunities for decentralized decision making ${ }^{\mathrm{u}}$ but also on optimizing the overall system and keeping the costs as low as possible while maintaining the goal. The location-related consequences of renewables for man and nature must also be considered in a comprehensive manner. ${ }^{\mathrm{v}}$ To do this, we need effective and efficient coordination of all the levels (national, state, regional, and municipal) and space- and process-related management. This is even the case for setting the goals for expanding renewables that affect infrastructure planning (networks and storage) and the related costs. Currently, the goals of the federal and state governments diverge significantly from one another with regard to expanding renewables [61-64]. New instruments are needed so that better coordinated decisions can be made, such as for a federal climate protection act [65], specialist technical planning at the federal level [66], or a strengthening of the Federal Spatial Planning Act. ${ }^{\mathrm{W}}$ In this way, the necessary orientation for state and regional planning decisions could be made as a prerequisite for investors' decisions on locations, unnecessary expansion costs could be avoided, and local disturbances by renewables could be limited. Not all spatial issues can be resolved, however, by central planning. The space and freedom for making market decisions, which are needed for achieving cost efficiency in spatial allocations, must be maintained as a matter of principle [63].

\section{Conclusion: the energy transition as a sustainability project}

The German energy transition is being watched critically around the world. It will be judged by whether and how far it succeeds in organizing the comprehensive sustainability of the energy supply in a highly industrialized country within a reasonable period of time and in maintaining profitability, security of supply, environmental compatibility, and social acceptability in equal measure. The challenges posed by the transformation of such a complex system are considerable, and we are still at the beginning of a long path. The difficulties that arise may not be played down, and the task of overcoming them requires ongoing scientific support as well as intensive public participation [67]. In the course of the energy transition, today's generations are investing in a sustainable system of energy supply. The energy transition is consequently an intergenerational contract. The temporally limited (additional) costs being borne today are supposed to lead to permanently lower costs and risks tomorrow. This goal makes the energy transition into an outstanding sustainability project. For this reason, it also continues to deserve our full support.

\section{Endnotes}

${ }^{a}$ The German Renewable Energy Sources Act (EEG) gives priority to feeding electricity from renewable sources into the power grid and guarantees firm rates of remuneration for this electricity (feed-in tariffs). On the discussion about the EEG, see e.g., $[68,69]$.

${ }^{\mathrm{b}}$ In the following, the authors of this article also focus their attention on the power sector since we shall primarily refer to the current power-related controversies about energy policy in Germany.

${ }^{\mathrm{c}}$ Large industrial consumers of electricity are required only to pay a strongly reduced EEG levy and are thus 
largely freed from financing the system providing support for renewables.

${ }^{\mathrm{d}}$ Affirmative with regard to this controversy is, e.g., $[70,71]$, while [72-75] is opposed (the prevailing opinion in German professional literature), and [76] is nuanced.

${ }^{\mathrm{e}}$ The so-called green power privilege ( $\mathbb{3} 39$ of the EEGAct) establishes a particularly reduced EEG-surcharge for suppliers only if $50 \%$ of the electricity portfolio is sourced from domestic renewable electricity. This might discriminate between domestic and imported electricity from renewable sources produced in similar plants.

${ }^{\mathrm{f}} \mathrm{See}$ [27]. The proceedings are governed by Article 6 of the decree on state aid proceedings (Council Regulation (EC) No. 659/1999).

${ }^{\mathrm{g}}$ See only [71, p. 317]. On the continued absence of involvement of the state sphere of financing for the EEG-Act 2012, see also [77].

${ }^{\mathrm{h}}$ Also according to $[72,73]$.

${ }^{\mathrm{i}}$ The determination that the support and compensation system in the EEG had the character of state aid would have disagreeable consequences for Germany even if a justification according to European law were successful. Any new aid would always have to be notified in advance and could only be granted following approval by the Commission (Article 108 (3) TFEU: ban on implementation). For the period of time from the introduction of the aid until its approval, there is the threat of repayment claims. On this, see [78] with extensive references to the relevant verdicts of the European Court of Justice.

'Austria's current suit against the Commission's decision of 8.3.2011 (C 24/2009, COM (2011) 1363 final) will presumably point the way ahead, which is over Austria's law on ecological electricity.

${ }^{\mathrm{k}}$ For more details, see [30,79].

${ }^{\mathrm{I}}$ The fact that aid models other than that using the EEG's feed-in remuneration could even increase the burden is shown in [80].

${ }^{\mathrm{m}}$ See e.g., [81-83].

${ }^{\mathrm{n}} \mathrm{See}[41,84]$. In the World Energy Outlook Special Report 2013, the International Energy Agency (IEA) calls improving energy efficiency to be, of the four most important measures for climate protection, that having the most leverage to avoid $\mathrm{CO}_{2}$.

${ }^{\circ}$ While the theoretical potential may be estimated to be high [85], there are markedly more restrained estimates for the savings that can be achieved in practice; see [86].

${ }^{\mathrm{P}} \mathrm{By}$ far, the greatest economic potential for savings in the period until 2020 , according to a recent study by dena, is in the area of heat and fuels (over 16\%), which is followed by motor fuels and not inconsiderable amounts of electricity (approximately 10\%); see [42]. See also [87].

${ }^{\mathrm{q}}$ On this important auxiliary condition for economic efficiency in addition to purely technical energy efficiency, see [88].
${ }^{\mathrm{r}}$ While renewables also contribute to avoiding or mitigating these nonclimatic (environmental) externalities, they admittedly also cause novel regional environmental costs with respect to nature conservation, animal protection, the landscape, waters, and residential environment, which have to be taken into consideration as a nonmonetary category of costs during such an expansion - see e.g. [89].

${ }^{\mathrm{s}}$ On the policy mix comprising the EU emissions trading scheme and the German EEG, see [13,90] or [91].

${ }^{t}$ See also [9].

${ }^{\mathrm{u}} \mathrm{See}$ on the legal opportunities to strengthen municipal competencies for climate protection [65]. On the opportunities and limits of an intensified public participation in planning processes see [67].

'See endnote 'r.'

${ }^{\mathrm{w}}$ See especially on the criticism of the marginalization of spatial planning resulting from the strengthening of technical planning and on the tasks of a federal spatial planning act the analysis in [92].

\section{Competing interests}

The authors declare that they have no competing interests.

\section{Authors' contributions}

Several authors drafted the first version of this manuscript. All authors contributed to revise and finalize this article. All authors read and approved the final manuscript.

\section{Authors' information}

The authors jointly conduct research in the Alliance ENERGY-TRANS established by the Helmholtz Association of German Research Centers. Alliance researchers examine the energy transition in Germany and the related demands it places on the transformation of the national and European energy system, especially from the perspective of societal demand and utility, and analyze the manifold interfaces between technical and social factors. The results should provide policy-oriented know-how for an efficient and socially acceptable organization of the future energy system. Further information can be found at www.energy-trans.de.

\section{Author details}

${ }^{1}$ Helmholtz Center for Environmental Research - UFZ, Permoser Str. 15, 04318 Leipzig, Germany. ${ }^{2}$ Center for European Economic Research (ZEW), 68034 Mannheim, Germany. ${ }^{3}$ Environmental Policy Research Center (FFU), Freie Universität Berlin, 14195 Berlin, Germany. ${ }^{4}$ Institute of Technical Thermodynamics, German Aerospace Center (DLR), 70569 Stuttgart, Germany. ${ }^{5}$ Stuttgart Research Center for Interdisciplinary Risk and Innovation Studies (ZIRIUS), University of Stuttgart, 70174 Stuttgart, Germany.

Received: 24 April 2014 Accepted: 10 June 2014 Published: 8 July 2014

\section{References}

1. Renewable Energies Agency [Agentur für Erneuerbare Energien - AEE] (2013) Akzeptanzumfrage (2013) Erneuerbare Energiewende ist bei Deutschen weiterhin hoch im Kurs, Renews Kompakt 18.9.2013, http://www.unendlich-viel-energie.de/ media/file/173.AEE_RenewsKompakt_Akzeptanzumfrage_Sep13.pdf. Accessed 14 Apr 2014

2. Federation of German Consumer Organisations (Verbraucherzentrale Bundesverband] (2013) Verbraucherinteressen in der Energiewende, Ergebnisse einer repräsentativen Befragung, 12.08.2013., http://www.vzbv.de/cps/rde/xbcr/ vzbv/Energiewende_Studie_lang_vzbv_2013.pdf. Accessed 14 Apr 2014

3. Renewable Energies Agency [Agentur für Erneuerbare Energien - AEE] (2012) Akzeptanz Erneuerbarer Energien in der deutschen Bevölkerung, Bundesländergenaue Ergebnisse einer repräsentativen Umfrage von TNS Infratest im Auftrag der Agentur für Erneuerbare Energien, Renews Special, 
Issue 56 March 2012, http://www.kommunal-erneuerbar.de/fileadmin/ content/PDF/56_Renews_Spezial_Akzeptanzumfrage_2011_online.pdf. Accessed 14 Apr 2014

4. German Association of Local Utilities Verband kommunaler Unternehmen VKU] (2012) FORSA-Umfrage zur Energiewende, Bürger sind bereit, in den Umbau des Energiesystems zu investieren, Presseinformation No. 03/2012. http://www.die-klima-allianz.de/wp-content/uploads/2012/01/

PM_03_12_Forsa-Umfrage_Energiewende_120104.pdf. Accessed 14 Apr 2014

5. Ohlhorst D (2011) Energiemix im Lobbygeflecht - das Ringen der Akteure um die Weichenstellungen für die Zukunft. In: Keppler, Nölting, Schröder (eds) Neue Energie im Osten - Gestaltung des Umbruchs, Perspektiven für eine zukunftsfähige sozial-ökologische Energiewende. Frankfurt/Main, pp 73-95

6. Büscher C, Schippl J (2013) Die Transformation der Energieversorgung: Einheit und Differenz soziotechnischer Systeme. Technology Assessment - Theory and Practice 22(2):11-19

7. Geels FW (2004) From sectoral systems of innovation to socio-technical systems: insights about dynamics and change from sociology and institutional theory. Research Policy 33(6-7):897-920. doi:10.1016/j.respol.2004.01.015

8. Löschel A, Erdmann G, Staiß F, Ziesing HJ (2012) Stellungnahme zum ersten Monitoring-Bericht der Bundesregierung für das Berichtsjahr 2011, Expertenkommission zum Monitoring-Prozess Energie der. Zukunft, Berlin

9. Gawel E, Hansjürgens B (2013) Projekt, Energiewende": Schneckentempo und Zickzackkurs statt klarer Konzepte für die Systemtransformation? Wirtschaftsdienst 93(5):283-288. doi:10.1007/s10273-013-1525-1

10. Bruns E, Ohlhorst D, Wenzel B, Köppel J (2011) Renewable energies in Germany's electricity market, A biography of the innovation process. Springer, Dordrecht. doi:10.1007/978-90-481-9905-1

11. Bruns E, Futterlieb M, Ohlhorst D, Wenzel B (2012) Netze als Rückgrat der Energiewende - Hemmnisse für die Integration erneuerbarer Energien in Strom-. Gas- und Wärmenetze, Berlin. doi:10.2314/GBV:749601205

12. Adolf M, Bruns E (2013) Erneuerbare Wärme in Deutschland: Dynamiken und Akteursinteressen bei der Nutzung biogener Festbrennstoffe. EnEV aktuell 7(3):11-14. doi:10.1007/s12398-012-0087-z

13. Lehmann P, Gawel E (2013) Why should support schemes for renewable electricity supplement the EU emissions trading scheme. Energy Policy 52:597-607. doi:10.1016/j.enpol.2012.10.018

14. Lehmann P (2013) Supplementing an emissions tax by a feed-in tariff for renewable electricity to address learning spillovers. Energy Policy 61:635-641. doi:10.1016/j.enpol.2013.06.072

15. Gawel E, Korte K, Lehmann P, Strunz S (2012) The German energy transition - is it really scandalous? GAiA 21(4):278-283

16. Küchler S, Meyer B (2012) Was Strom wirklich kostet: Vergleich der staatlichen Förderungen und gesamtgesellschaftlichen Kosten konventioneller und erneuerbarer Energien, http://www.foes.de/pdf/201208-Was_Strom_wirklich_kostet_lang.pdf, Accessed 14 Apr 2014

17. Lehmann P, Creutzig F, Ehlers MH, Friedrichsen N, Heuson C, Hirth L, Pietzcker R (2012) Carbon lock-out: advancing renewable energy policy in Europe. Energies 5(2):323-354. doi:10.3390/en5020323

18. Gawel E (2013) "Fundamental rearrangement" of the German Renewable Energy Sources Act - but how is this to be achieved? Wirtschaftsdienst 93(11):785-792. doi:10.1007/s10273-013-1599-9

19. Schober D, Woll O, Weber C (2012) Efficient use of renewables integration instruments under peak-load pricing - fixed feed-in tariffs vs. bonus systems, Proceedings of the Mannheim Energy Conference

20. Löschel A, Flues F, Pothen F, Massier P (2013) Den Strommarkt an die Wirklichkeit anpassen: Skizze einer neuen Marktordnung, ZEW Discussion Paper 13-065. Mannheim. doi:10.2139/ssrn.2325298

21. Gawel E, Klassert C (2013) Probleme der besonderen Ausgleichsregelung im EEG. Zeitschrift für Umweltrecht 24(9):467-480

22. Gawel E, Klassert C (2012) Besondere Ausgleichsregelung im EEG: Quo vaderis? Energiewirtschaftliche Tagesfragen 63(10):29-34

23. European Commission (2013) State aid: Commission opens in-depth inquiry into support for energy-intensive companies benefitting from a reduced renewables surcharge, IP/13/1283, 18.12.2013. http://europa.eu/rapid/press-release_IP-131283_en.htm Accessed 14 Apr 2014

24. Löschel A, Flues F, Heindl P (2012) Zeitgespräch: Verteilungswirkungen des Erneuerbare-Energien-Gesetzes - Das Erneuerbare-Energien-Gesetz in der Diskussion. Wirtschaftsdienst 92(8):515-519. doi:10.1007/s10273-012-1413-0

25. European Court of Justice [ECJ] 13 March 2001, Case C-379/98, PreussenElektra, para 59

26. European Court of Justice [EC] 17 July 2008, Case C-206/06., Essent, para 74
27. EU Commission (2014) State aid SA.33995 (2013/C) (ex 2013/NN) — support for renewable electricity and reduced EEG-surcharge for energy-intensive users, Official J EU 2014/C C 37/73-C37/111

28. Commission E (2008) Community guidelines of 1 April 2008 on state aid for environmental protection, Official Journal C 82:1-33, 1 April 2008

29. European Commission (2013) Draft guidelines on Environmental and Energy State Aid for 2014-2020 (EEAG), http://ec.europa.eu/competition/consultations/2013_state_aid_environment/index_en.html

30. Tews K (2013) Energiearmut definieren, identifizieren und bekämpfen - Eine Herausforderung der sozialverträglichen Gestaltung der Energiewende Vorschlag für eine Problemdefinition und Diskussion des Maßnahmenportfolios, FFU-Report 2013(4). Berlin

31. Gawel E, Korte K (2012) Verteilungseffekte des EEG: Kritik an den falschen Stellen. Wirtschaftsdienst 92(8):512-515. doi:10.1007/s10273-012-1413-0

32. Neuhoff K, Bach S, Diekmann J, Beznoska M, El-Laboudy T (2013) Distributional effects of energy transition: impacts of renewable electricity support in Germany. Econ Energy Environ Policy 2(1):41-54. doi:10.5547/2160-5890.2.1.3

33. Tews K (2014) Fuel poverty in Germany: from a buzzword to a definition. GAIA 23(1):14-18. doi:10.14512/gaia.23.1.6

34. Gawel E, Korte K, Tews K et al (2014) Energiewende im Wunderland, Über Sozialmythen der Förderung Erneuerbarer, UFZ Discussion Paper 2014(19). Leipzig

35. Haller M, Herrmann H, Loreck C, Matthes F, Cook V (2013) EEG-Umlage und die Kosten der Stromversorgung für 2014, Eine Analyse von Trends, Ursachen und Wechselwirkungen. Study prepared for Greenpeace, Berlin

36. Gawel E, Korte K, Lehmann P, Strunz S (2012) Kosten der Energiewende - Fakten und Mythen. Energiewirtschaftliche Tagesfragen 62(11):39-44

37. Reeg M, Kober B (2013) Gestaltungsoptionen für ein Strommarktdesign mit hohen Anteilen erneuerbarer Energien. Energiewirtschaftliche Tagesfragen 63(7):33-38

38. Heim S, Götz G (2013) Do pay-as-bid auctions favor collusion? Evidence from Germany's market for reserve power, ZEW Discussion Paper No. 13-035. Mannheim. doi:10.2139/ssrn.2278873

39. German Energy Agency [Deutsche Energie-Agentur, dena] (2014) Initiative EnergieEffizient - Ein starkes Bündnis für Stromeffizienz, http://www.dena. de/projekte/stromnutzung/initiative-energieeffizienz-ein-starkes-buendnisfuer-stromeffizienz.html

40. Monopolies Commission [Monopolkommission] (2013) Energie 2013: Wettbewerb in Zeiten der Energiewende, Special Report 65. doi:10.5771/ 9783845251578

41. Kohler S, Agricola AC, Joest S, Peters S, Stolte C (2013) Energieeffizienz als Säule der Energiewende. Energiewirtschaftliche Tagesfragen 63(11):8-15

42. dena/Frontier Economics (2012) Steigerung der Energieeffizienz mit Hilfe von Energieeffizienz-Verpflichtungssystemen, http://www.dena.de/fileadmin/user_upload/Presse/studien_umfragen/Energieeffizienz-Verpflichtungssysteme/Studie_Energieeffizienz-Verpflichtungssysteme_EnEffVSys.pdf. Accessed 14 Apr 2014

43. Vohrer P, Mühlenhoff J, Müller A, Nawroth C (2013) Erneuerbare Wärme: Klimafreundlich, wirtschaftlich, technisch ausgereift, Renews Spezial No. 63. Berlin

44. Gallego Carrera D, Wassermann S, Weimer-Jehle W, Renn O (2012) Nachhaltige Nutzung von Wärmeenergie, Eine technische, soziale und ökonomische Herausforderung. Vieweg + Teubner, Wiesbaden

45. Gallego Carrera D, Wassermann S, Zech D (2012) Suffizienz, Effizienz, Konsistenz: Wege zur nachhaltigen Wärmeenergienutzung in Privathaushalten. Ökologisches Wirtschaften 2012(3):45-50

46. Achtnicht M (2011) Do environmental benefits matter? Evidence from a choice experiment among house owners in Germany. Ecological Economics 70(11):2191-2200. doi:10.1016/j.ecolecon.2011.06.026

47. Achtnicht M, Madlener R (2014) Factors influencing German house owners' preferences on energy retrofits. Energy Policy 68:254-263. doi:10.1016/j. enpol.2014.01.006

48. Bruns E, Futterlieb M, Ohlhorst D, Wenzel B (2012) Erneuerbare Energien in Wärmenetzen - eine realistische Perspektive? Zeitschrift für Energiewirtschaft 36(3):159-172. doi:10.1007/s12398-012-0087-z

49. Allcott $\mathrm{H}$, Greenstone M (2012) Is there an energy efficiency gap? Journal of Economic Perspectives 26(1):3-28. doi:10.1257/jep.26.1.3

50. Achtnicht M (2012) German car buyers' willingness to pay to reduce CO emissions. Climatic Change 113(3):679-697. doi:10.1007/s10584-011-0362-8

51. Gawel E, Strunz S, Lehmann P (2014) Wie viel Europa braucht die Energiewende? UFZ Discussion Paper 2014(4). Leipzig

52. Lehmann P, Strunz S, Gawel E, Korte K (2014) EU energy policy beyond 2020. Benefits of a policy mix. GAiA 23(1):60-61. doi:10.14512/gaia.23.1.15 
53. Lehmann P, Sijm J, Gawel E, Chewpreecha U, Pollit H, Strunz S (2014) EU climate and energy policy in 2030: how many targets and instruments are necessary? UFZ Discussion Paper 2014(3). Leipzig

54. Flues F, Löschel A, Lutz BJ, Schenker O (2013) Ups and downs. How economic growth affects policy interactions, ZEW Discussion Paper No. 13066. Mannheim. doi:10.2139/ssrn.2333574

55. Böhringer C, Löschel A, Moslener U, Rutherford TF (2009) EU climate policy up to 2020: an economic impact assessment. Energy Economics 31(S2):295-305. doi:10.1016/j.eneco.2009.09.009

56. Löschel A, Gallier C, Lutz BJ, Brockmann KL, Dickhöner C (2013) KfW/ZEW $\mathrm{CO}_{2}$-barometer 2013 - carbon edition, The EU emissions trading scheme: firm behavior during the crisis, http://ftp.zew.de/pub/zew-docs/co2panel/ CO2Barometer2013.pdf. Accessed 14 Apr 2014

57. Bruns E, Ohlhorst D (2012) Innovationsbiographien erneuerbarer Energien im Stromsektor: Impulse durch StrEG und EEG im Wechselspiel mit heterogenen treibenden Kräften. In: Müller T (ed) 20 Jahre Recht der Erneuerbaren Energien. Nomos, Baden-Baden, pp 162-193

58. Eucken W (1990) Grundsätze der Wirtschaftspolitik, 6th edn. JCB Mohr, Tübingen

59. Schreurs M (2008) From the bottom up: local and subnational climate change politics. J Environ Dev 17(4):343-355. doi:10.1177/1070496508326432

60. Schreurs M (2013) Orchestrating a low carbon energy future without nuclear: Germany's response to the Fukushima nuclear crisis. Theoretical Ing L 14(1):83-108. doi:10.1515/til-2013-006

61. Ohlhorst D, Tews K, Schreurs M (2013) Energiewende als Herausforderung der Koordination im Mehrebenensystem. Technology Assessment - Theory and Practice 22(2):48-55

62. Ohlhorst D, Tews K (2013) Deutschland als Laboratorium: Das Experiment Energiewende. In: Varwick (ed) Energiewende. Wochenschau-Verlag, Schwalbach, pp 26-46

63. Gawel E, Korte K (2014) Regionale Verteilungswirkungen und Finanzierungsverantwortung: Bund und Länder bei der Strom Energiewende. In: Müller (ed) Energiewende im Föderalismus. Baden-Baden, in preparation

64. Mez L, Schneider S, Reiche D, Tempel S, Klinski S, Schmitz E (2007) Zukünftiger Ausbau erneuerbarer Energieträger unter besonderer Berücksichtigung der Bundesländer. Berlin

65. Rodi M, Sina S, Görlach B, Gerstetter C, Bausch C, Neubauer A (2011) Das Klimaschutzrecht des Bundes - Analyse und Vorschläge zu seiner Weiterentwicklung. Federal Environment Agency, Dessau-Roßlau

66. Hermes G (2014) Planungsrechtliche Sicherung einer Energiebedarfsplanung. Zeitschrift für Umweltrecht 25(5):259-269

67. Renn O, Köck W, Schweizer PJ, Bovet J, Benighaus C, Scheel O, Schröter R (2013) Public participation within the German Energiewende. Policies and guidelines for planning processes. GAiA 22(4):279-280

68. German Council of Economic Experts [Sachverständigenrat zur Begutachtung der gesamtwirtschaftlichen Entwicklung] (2011) Assume responsibility for Europe, Annual Report 2011/2012. Wiesbaden, http://www. sachverstaendigenrat-wirtschaft.de/aktuellesjahrsgutachten0.html?\&L=1. Accessed 14 Apr 2014

69. Acatech (2012) Die Energiewende finanzierbar gestalten, Effiziente Ordnungspolitiken für das Energiesystem der Zukunft, acatech POSITION, September 2012, http://www.acatech.de/fileadmin/user_upload/ Baumstruktur_nach_Website/Acatech/root/de/Publikationen/Stellungnahmen/ acatech_POSITION_Energiewende_WEB.pdf. Accessed 14 Apr 2014

70. Bloch J (2014) Die Befreiung von der EEG-Umlage als staatliche Beihilfe Vereinbarkeit mit dem Gemeinsamen Markt. Recht der Energiewirtschaft 24(1):14-21

71. Ismer R, Karch A (2013) Das EEG im Konflikt mit dem Unionsrecht: Die Begünstigung der stromintensiven Industrie als unzulässige Beihilfe. Zeitschrift für Umweltrecht 24(10):526-535

72. Schlacke S, Kröger J (2013) Die Privilegierung stromintensiver Unternehmen im EEG. Eine unionsrechtliche Bewertung der besonderen Ausgleichsregelung ( $\S \S$ 40 ff. EEG). Neue Zeitschrift für Verwaltungsrecht 32(6):313-319

73. Kahles M, Stehle A, Pause F, Müller (2013) EEG und Beihilfe, Kurzüberblick übe aktuelle Fragestellungen aus rechtlicher Sicht. Würzburg, http://www.stiftungumweltenergierecht.de/fileadmin/pdf_aushaenge/wiss._Veroeff/ Stiftung_Umweltenergierecht_Beihilfediskussion_EEG_2013-03-11.pdf. Accessed 14 Apr 2014

74. Greinacher D (2013) Besondere Ausgleichsregelung als Beihilfe? Energierecht 2(3):97-101
75. Gawel E, Strunz S (2014) State aid dispute on Germany's support for renewables: is the Commission on the right course? J Eur Environ Plann Law 11(2):139-152

76. Ekardt F (2013) Energiewende und EU-Beihilfenrecht: EEG-Förderung EEG-Ausnahmen, Atomrecht, Energiesteuern. Europäisches Umwelt- und Planungsrecht 11(3):197-205

77. Gawel E (2013) Die EEG-Umlage: Preisregelung oder Sonderabgabe? Deutsches Verwaltungsblatt 128(7):409-417

78. Bär-Bouyssière B (2012) In: Schwarze et al (eds) EU-Kommentar, 3rd edn., on Article 108 TFEU, Baden-Baden, note 9

79. Heindl $P$ (2013) Measuring fuel poverty: general considerations and application to German household data, ZEW Discussion Paper No. 13-046. Mannheim

80. Weber C, Schober D, Woll O (2012) Renewable support and $\mathrm{CO}_{2}$-abatement in open economies - the role of price discrimination. IAEE Conference Proceedings, Perth, pp 24-27, June 2012

81. Cramton P, Ockenfels A (2012) Economics and design of capacity markets for the power sector. Zeitschrift für Energiewirtschaft 36(2):113-134. doi:10.1007/s12398-012-0084-2

82. European Energy Exchange [EEX] (2013) Notwendigkeit und Design von Kapazitätsmechanismen, Positionspapier der European Energy Exchange AG. Leipzig, http://cdn.eex.com/document/143198/20130805_EEX-

Position_Kapazitätsmechanismen.pdf Accessed 18 Apr 2014

83. Böckers V, Giessing L, Haucap J, Heimeshoff U, Rösch J (2012) Braucht Deutschland einen Kapazitätsmarkt für Kraftwerke? Eine Analyse des deutschen Marktes für Stromerzeugung., Ordnungspolitische Perspektiven No. 26, 2012, Düsseldorf

84. German Advisory Council on the Environment [Sachverständigenrat für Umweltfragen] (2011) Pathways towards a 100\% renewable electricity system, Special Report. Wiesbaden

85. Bürger V (2009) Identifikation, Quantifizierung und Systematisierung technischer und verhaltensbedingter Stromeinsparpotenziale privater Haushalte., Transpose Working Paper No. 3, Münster

86. Tews K (2012) Einzelprojektevaluierung: Stromspar-Check in einkommensschwachen Haushalten. In: Öko-Institut et al (eds) Evaluierung des nationalen Teils der Klimaschutzinitiative des BMU. Berlin, appendix A22

87. Jochem E, Lösch O, Mai M, Mielicke U, Reitze F (2014) Energieeffizienz in der deutschen Industrie - brachliegende Chancen. Energiewirtschaftliche Tagesfragen 64(2):81-85

88. Mennel T, Sturm B (2009) Energieeffizienz - eine neue Aufgabe staatlicher Regulierung? Zeitschrift für Wirtschaftspolitik 58(1):3-35

89. Demuth B, Heiland S, Wiersbinski N, Ammermann K (2013) Energielandschaften - Kulturlandschaften der Zukunft? Energiewende Fluch oder Segen für unsere Landschaften? BfN-Skripten 337, Bonn

90. Gawel E, Lehmann P (2011) Macht der Emissionshandel die Förderung erneuerbarer Energien überflüssig? Energiewirtschaftliche Tagesfragen 61(3):24-29

91. Gawel E, Strunz S, Lehmann P (2014) A public choice view on the climate and energy policy mix in the EU - how do the emissions trading scheme and support for renewable energies interact? Energy Policy 64:175-182. doi:10.1016/j.enpol.2013.09.008

92. Durner W (2009) Das neue Raumordnungsgesetz. Natur und Recht 31(6):373-380. doi:10.1007/s10357-009-1677-3

doi:10.1186/s13705-014-0015-7

Cite this article as: Gawel et al.: The future of the energy transition in Germany. Energy, Sustainability and Society 2014 4:15. 